\title{
Hubungan Karakteristik Keluarga Kurang Mampu dengan Kejadian Stunting pada Balita di Kota Semarang
}

\author{
Santi Mutiara Purnama Asri*, M. Zen Rahfiludin **, Martini ** \\ *Brilliant Music School, Jakarta Utara, \\ ** Fakultas Kesehatan Masyarakat, Universitas Diponegoro \\ Email: santimutiara2010@gmail.com
}

\section{ABSTRACT}

The classification of a family is said to be poor judged by several indicators, namely the ability of the family to obtain ownership of clothing (clothing), obtain food, proper conditions of residence (board), affordability of education and health, income, and asset ownership. a long-term indicator of malnutrition which is the impact of a failure of growth in the past that will hinder the development of children in the future.

This study aimed to link the characteristics of poor families to the incidence of stunting in infants in the city of Semarang. This study used case control design with a purposive sampling technique. The study subjects were 91 stunting toddlers (cases) and 91 normal toddlers (controls). The variables measured were parenting, mother's education, father's education, mother's work, family income, knowledge of maternal nutrition.

The results of this study showed that there was significant relationship between parenting, knowledge of maternal nutrition, maternal education, father's education and family income with the incidence of stunting in the city of Semarang. This was indicated by p-value $<0,0001, \quad O R=12,632$ in the variable parenting style, maternal nutritional knowledge (p-value <0,0001, OR = 9,273), maternal education ( $p$-value $=0,002, O R$ $=2,857), p$-value $=0.006$, OR $=2.842$ on father's education variables, and family income ( $p$-value $=0.037$, OR $=2.738$ ).

Keywords: Stunting, Toddlers, Family Income

\section{PENDAHULUAN}

Anak balita adalah anak dengan usia 12 bulan sampai dengan 60 bulan. $^{3}$ Anak balita merupakan kelompok yang menunjukkan pertumbuhan badan yang pesat. Peran penting gizi pada kehidupan anak usia pra sekolah, dapat mempengaruhi pertumbuhan fisiknya. Anak usia 12-36 bulan (1-3 tahun) adalah salah satu kelompok konsumen pasif yang menerima makanan berdasarkan dengan yang disediakan oleh ibu, sedangkan usia pra sekolah (4-5 tahun) merupakan konsumen aktif yang sudah bisa memilih sendiri makanan yang disukai dan tidak disukainya. Pertumbuhan anak semasa balita juga dapat dipengaruhi dari gizi ibu pada masa konsepsi sampai masa hamil muda. ${ }^{3,4}$

Penilaian status gizi anak dipantau menggunakan antropometri. Pengukuran status gizi dengan menggunakan indeks Panjang Badan menurut Umur $(\mathrm{PB} / \mathrm{U})$ atau Tinggi Badan menurut Umur (TB/U) dikenal dengan istilah stunted (pendek) dengan $z$-score $=-3$ SD sampai dengan $<$ - 
$2 \mathrm{SD}$, severely stunted (sangat pendek) dengan $z$-score $=<-3 \mathrm{SD}$, normal dengan $z$-score $=-2 \mathrm{SD}$ sampai dengan $2 \mathrm{SD}$, dan tinggi dengan $z$-score $=>2$ SD. ${ }^{5,6}$ Stunting pada anak merupakan salah satu indikator jangka panjang dari kegagalan pertumbuhan di masa lalu yang akan menghambat perkembangan anak di masa mendatang Permasalahan stunting ini merupakan gangguan pertumbuhan dan perkembangan yang tidak dapat dipulihkan. ${ }^{4,7}$

Stunting disebabkan oleh faktor multi dimensi, yaitu praktek pengasuhan yang tidak baik sejak 1000 Hari Pertama Kehidupan (HPK) anak, pengetahuan ibu tentang kesehatan dan gizi sebelum dan pada masa kehamilan yang minim, anak usia 0-24 bulan tidak mendapat ASI eksklusif, pemberian Makanan Pendamping ASI (MP-ASI) dibawah standar usia yang disarankan, terbatasnya layanan kesehatan (termasuk layanan Ante Natal Care, Post Natal dan pembelajaran dini yang berkualitas), kurangnya akses mendapat makanan bergizi, kurangnya akses mendapatkan air bersih dan sanitasi. ${ }^{8}$ Pengasuhan yang biasa dilakukan ibu kepada anak seperti praktik pemberian makan, praktik sanitasi dan perawatan kesehatan kepada anak. $^{2}$

Klasifikasi sebuah keluarga dikatakan miskin dinilai oleh beberapa indikator, yaitu kemampuan keluarga memperoleh kepemilikan pakaian (sandang), mendapatkan pangan, kondisi tempat tinggal (papan) yang layak, terjangkaunya akses pendidikan dan kesehatan, pendapatan, serta kepemilikan aset. ${ }^{1}$ Pada Kota Semarang, warga dikatakan miskin jika memiliki pendapatan <Rp. 368.477,00 / kapita / bulan. ${ }^{9}$

Pada skala nasional, prevalensi stunting pada anak balita tahun 2013, yaitu $37,2 \%$. Prevalensi stunting (pendek) di Provinsi Jawa Tengah pada tahun 2013 yaitu sebesar 33,9\% dan tahun 2017 sebesar 20,60\%, sedangkan di Kota Semarang prevalensi stunting sebesar $20,37 \%$ pada tahun 2013. ${ }^{10,11,12}$ Pada tahun
2017, dari 16 kecamatan yang ada di Kota Semarang, kecamatan Candisari memiliki prevalensi stunting yang tinggi yaitu sebesar 39,22\% yang berasal dari keluarga miskin dan Puskesmas Kagok memiliki prevalensi kejadian stunting sebesar $59,57 \%$ berasal dari keluarga miskin. ${ }^{13}$

Dikarenakan status sosial ekonomi, letak rumah warga yang jauh dan kondisi jalan yang ektsrim menanjak dan menurun dari Puskesmas maupun Posyandu serta masih kurangnya kesadaran masyarakat terhadap gizi dan kesehatan anak. Selain itu belum ada evaluasi, penelitian maupun penanganan tentang kasus stunting atau balita pendek dari Posyandu maupun Puskesmas di wilayah Kelurahan Tegalsari, membuat peneliti tertarik untuk meneliti wilayah tersebut dan menganalisis bagaimana cara pola pengasuhan orang tua terhadap gizi anak sehingga mengakibatkan angka kejadian stunting tinggi di wilayah tersebut.

\section{METODE PENELITIAN}

Penelitian ini dilakukan di Kota Semarang pada bulan Maret-Agustus 2018 dengan rancangan penelitian case control. Populasi dalam penelitian ini adalah semua balita yang ditimbang dan berada di wilayah kerja Puskesmas Kagok pada tahun 2017. Subyek penelitian ini berdasarkan tabel proporsi dan Odds Ratio dari penelitian sebelumnya dan perhitungan sampel minimal, kemudian didapatkan hasil sebanyak 182 responden (91 responden kasus dan 91 responden kontrol). Prosedur pemilihan sampel menggunakan purposive sampling. Data dikumpulkan dengan wawancara menggunakan kuesioner terstruktur, observasi, dan pengukuran anthropometry balita secara langsung. Data dianalisis menggunakan uji hubungan chi-square.

\section{HASIL DAN PEMBAHASAN}

Karakteristik keluarga responden pada penelitian ini meliputi variabel pola asuh orang tua, pendidikan ibu, pendidikan ayah, pekerjaan ibu, pendapatan keluarga, 
dan pengetahuan gizi ibu, pada kelompok kasus dan kontrol yang kemudian ditabulasi silang dengan variabel kejadian stunting.

Tabel 1. Karakteristik Keluarga Kurang Mampu dengan Kejadian Stunting

\begin{tabular}{|c|c|c|c|c|}
\hline \multirow{2}{*}{ Variabel } & \multicolumn{2}{|c|}{ Kejadian Stunting } & \multirow{2}{*}{ p-value } & \multirow{2}{*}{$\begin{array}{c}\text { OR } \\
(95 \% \mathrm{CI})\end{array}$} \\
\hline & $\begin{array}{c}\text { Kasus } \\
(n=91),(\%)\end{array}$ & $\begin{array}{c}\text { Kontrol } \\
(\mathbf{n}=91),(\%)\end{array}$ & & \\
\hline $\begin{array}{l}\text { Pola Asuh Orang Tua } \\
\text { Kurang baik }(\text { skor <69) } \\
\text { Baik }(\geq 69)\end{array}$ & $\begin{array}{l}70(76,9) \\
21(23,1)\end{array}$ & $\begin{array}{l}19(20,9) \\
72(79,1)\end{array}$ & $\mathbf{0 , 0 0 0 1} *$ & $\begin{array}{c}12,632 \\
(6,258-25,498)\end{array}$ \\
\hline $\begin{array}{l}\text { Pendidikan Ibu } \\
\text { Rendah (SD/SLTP) } \\
\text { Tinggi (SMA / Akademi / } \\
\text { Perguruan Tinggi) }\end{array}$ & $\begin{array}{l}42(46,2) \\
49(53,8)\end{array}$ & $\begin{array}{l}21(23,1) \\
70(76,9)\end{array}$ & $\mathbf{0 , 0 0 2} *$ & $\begin{array}{c}2,857 \\
(1,509-5,410)\end{array}$ \\
\hline $\begin{array}{l}\text { Pendidikan Ayah } \\
\text { Rendah (SD/SLTP) } \\
\text { Tinggi (SMA / Akademi / } \\
\text { Perguruan Tinggi) }\end{array}$ & $\begin{array}{l}31(34,1) \\
60(65,9)\end{array}$ & $\begin{array}{l}14(15,4) \\
77(84,6)\end{array}$ & $0,006 *$ & $\begin{array}{c}2,842 \\
(1,389-5,813)\end{array}$ \\
\hline $\begin{array}{l}\text { Pekerjaan Ibu } \\
\text { Bekerja } \\
\text { Tidak bekerja }\end{array}$ & $\begin{array}{l}16(17,6) \\
75(82,4)\end{array}$ & $\begin{array}{l}28(28,8) \\
65(71,4)\end{array}$ & 0,113 & $\begin{array}{c}\mathbf{0 , 5 3 3} \\
(\mathbf{0 , 2 6 3 - 1 , 0 8 0 )}\end{array}$ \\
\hline $\begin{array}{l}\text { Pendapatan Keluarga } \\
\text { Rendah ( } \leq \text { Rp. } 368.477,00 \\
\text { per kapita per bulan) } \\
\text { Tinggi (>Rp.368.477,00 } \\
\text { per kapita per bulan) }\end{array}$ & $\begin{array}{c}83(91,2) \\
8(8,8)\end{array}$ & $\begin{array}{l}72(79,1) \\
19(20,9)\end{array}$ & $0,037 *$ & $\begin{array}{c}2,738 \\
(1,131-6,629)\end{array}$ \\
\hline $\begin{array}{l}\text { Pengetahuan Gizi Ibu } \\
\text { Kurang paham (skor <42) } \\
\text { Paham (skor } \geq 42 \text { ) }\end{array}$ & $\begin{array}{l}69(75,8) \\
22(24,2)\end{array}$ & $\begin{array}{l}2325,3) \\
68(74,7)\end{array}$ & $0,0001 *$ & $\begin{array}{c}9,273 \\
(4,728-18,187)\end{array}$ \\
\hline
\end{tabular}

*) uji chi-square

\section{Hubungan Pola Asuh Orang Tua Dengan Kejadian Stunting}

Hasil uji chi-square menunjukkan bahwa ada hubungan antara pola asuh orang tua terhadap kejadian stunting pada balita dengan proposi pola asuh yang kurang baik pada kasus stunting lebih banyak sebesar $76,9 \%$ dibandingkan dengan kontrol (normal) sebesar 20.9\% ( $p$ value $<0,0001, \quad \mathrm{OR}=17,987, \quad \mathrm{CI}=8,552-$ 37,832). Hasil penelitian ini sesuai dengan penelitian di Desa Wawatu Kabupaten Konawe Selatan yang menyebutkan adanya hubungan yang signifikan antara pola asuh Ibu dengan kejadian stunting pada balita usia 24-59 bulan ( $p$ value $=0,001) .{ }^{14}$ Hasil ini tidak sejalan dengan penelitian pada daerah nelayan di Kampung Tambak Lorok, Kota Semarang yang menyebutkan bahwa pola asuh gizi yang tidak baik bukan merupakan faktor risiko kejadian stunting ( $p$-value $=0,193) .{ }^{15}$

Pola asuh orang tua dikatakan baik jika praktik sanitasi dan perawatan kesehatan pada balita dilakukan dengan baik dan pola asuh makan anak teratur dengan jadwal $3 x$ makan utama dan $3 x$ pemberian makanan selingan bernutrisi.

Perilaku mencuci tangan dengan sabun dan air bersih sebelum menyiapkan, menyajikan dan menyuapi anak ditemukan 
sejumlah $36,3 \%$ pada kasus stunting lebih sedikit dibandingkan dengan kontrol sebesar $76 \%$. Ditemukan $6,6 \%$ pada kasus stunting pengunaan sumber air bersih untuk kebutuhan mandi, mencuci, memasak dibedakan dengan kebutuhan minum dan jarak $>10$ m dengan septic tank lebih sedikit dibandingkan dengan kontrol sebesar $18,7 \%$. Ditemukan $<50 \%$ perilaku ibu membiasakan anak memakai alas kaki, mandi $2 \mathrm{x}$ sehari dan cuci rambut setiap hari pada kasus stunting lebih seidkit dibandingkan dengan kontrol 63,7\% Hal ini mencerminkan perilaku sanitasi yang dilakukan orang tua buruk. Perilaku tersebut dapat menjadi vektor pembawa dan penyebab penyakit yang ditularkan melalui kuman penyakit dari kaki dan tangan yang kotor, adanya pencemaran sumber air bersih serta penggunaan jamban yang tidak sehat. Perilaku sanitasi yang baik antara lainnya tidak membuang air besar sembarangan, penggunaan jamban sehat, perilaku mencuci tangan menggunakan sabun dan air bersih yang mengalir, serta perilaku menjaga kebersihan anak. ${ }^{16}$

Pada penelitiannya Herlina berpendapat bahwa pola asuh dalam pemberian makan yang tepat akan membuat status gizi anak menjadi lebih baik dan memungkinkan anak mendapat asupan zat gizi yang baik sesuai dengan tingkat kebutuhan dalam pertumbuhan tubuh dan membuat risiko terjadinya stunting lebih kecil. ${ }^{17}$ Hasil penelitian ini sesuai dengan pendapat Herlina. Pada penelitian ini ditemukan pemberian makan anak sehari-hari dengan memperhitungkan kebutuhan zat gizi anak terlebih dahulu pada kasus stunting sebanyak 53 responden $(58,2 \%)$ lebih banyak dibandingkan dengan kontrol $(13,2 \%)$. Pola asuh makan seperti ini meurpakan salah satu pola asuh makan yang tidak baik dilakukan oleh orang tua kepada anak. Asupan makan pada balita sepenuhnya diatur orang tua terutama ibu, status gizi anak yang baik dikarenakan pola asuh orang tua pun baik, namun jika pola asuh kurang baik, anak akan cenderung mengalami pertumbuhan yang tidak optimal. ${ }^{18}$

Adanya hubungan yang signifikan antara pola asuh ibu berupa praktik pemberian makan dengan kejadian stunting juga didukung dengan penelitian yang dilakukan Rahmayana di wilayah pesisir Kecamatan Tallo Kota Makassar pada balita usia 24-59 bulan. ${ }^{15}$

Pemberian makanan pada anak adalah landasan utama dalam proses pertumbuhan. Sekitar 30\% anak stunting dikarenakan konsekuensi dari praktik pemberian makanan yang buruk. Makanan pendamping ASI (MP-ASI) harus diberikan agar tercukupinya nutrisi bayi setelah bayi berusia 6 bulan dan selama periode usia 18-24 bulan yang dinyatakan masa rentan mudah terserang berbagai penyakit dan malnutrisi terjadi. Makanan yang diberikan harus dari berbagai jenis makanan yang bervariasi, cukup dalam jumlah, konsistensi, dan frekuensi sesuai dengan kebutuhan nutrisi selama masa pertumbuhan. ${ }^{19}$ Hal ini sesuai dengan pendapat Brigitte pada penelitian di wilayah pesisir Kecamatan Tallo yang menunjukkan adanya hubungan bermakna antara perhatian/dukungan ibu terhadap anak dalam praktek pemberian makanan, persiapan dan penyimpanan dengan pertumbuhan panjang badan anak dan kejadian stunting. ${ }^{20}$

\section{Hubungan Pendidikan Ibu Dengan Kejadian Stunting Pada Balita}

Pendidikan ibu yang rendah pada kasus stunting lebih banyak sebanyak 42 responden $(46,2 \%)$ dibandingkan dengan kontrol (normal) sebanyak 23,1\%. Hasil uji chi-square menunjukkan bahwa ada hubungan antara pendidikan ibu terhadap kejadian stunting pada balita dan memiliki risiko 2,857 kali lebih tinggi mengalami stunting dibandingkan dengan balita normal ( $p$-value $=0,002, \quad \mathrm{OR}=2,857$ dan $\mathrm{CI}=1,509-5,410)$.

Hasil ini serupa dengan penelitian di Provinsi Papua Barat yang menunjukkan bahwa ada hubungan yang signifikan 
antara pendidikan ibu dengan kejadian stunting $(p$-value $=0,043) .{ }^{21}$ Penelitian di Desa Bojonggede Kabupaten Bogor juga menyebutkan bahwa pendidikan ibu yang rendah memiliki hubungan bermakna dengan status gizi balita berdasarkan indeks $\mathrm{TB} / \mathrm{U}(p$-value $=0,005) .{ }^{17}$ Hasil ini tidak sejalan dengan penelittian yang dilakukan oleh Isninda yang menyebutkan bahwa pendidikan ibu yang rendah bukan merupakan faktor risiko kejadian stunting $(p$-value $=0,301){ }^{15}$

Sebuah teori mengatakan bahwa mekanisme hubungan pendidikan ibu dengan kesehatan anak terdiri dari pengetahuan tentang kesehatan dari pendidikan formal dan kemampuan melek huruf yang berfungsi dalam membaca masalah kesehatan yang dialami oleh anak serta melakukan perawatan beserta pajanan terhadap kehidupan masa kini. ${ }^{22}$ Teori ini sejalan dengan penelitian yang dilakukan pada siswa sekolah dasar di Kecamatan Lut Tawar, Kabupaten Aceh Tengah yang memperlihatkan hasil adanya hubungan yang signifikan antara pendidikan ibu dengan status gizi $(p<0,0001){ }^{23}$ Namun tidak sejalan dengan penelitian yang peneliti lakukan di Kota Semarang, hal ini dikarenakan pendidikan ibu tidak mempengaruhi pola pengasuhan terhadap anak, karena kemahiran ibu dalam mengasuh anak tidak selalu berkaitan dengan pendidikan ibu. Pengetahuan tentang pengasuhan dapat diakses dari luar pendidikan formal, sehingga ibu berpendidikan rendah belum tentu tidak tahu tentang cara mengasuh anak yang baik dan begitu pula dengan ibu berpendidikan tinggi, melainkan tergantung dari bagaimana ibu menerapkan pengasuhan yang baik terhadap anak.

\section{Hubungan Pendidikan Ayah Dengan Kejadian Stunting Pada Balita}

Hasil penelitian ini menunjukkan bahwa pendidikan ayah rendah pada kasus stunting lebih banyak sebesar 83 responden (91,2\%) dibandingkan dengan kontrol (normal) sebesar 79,1\%. Hasil uji chi- square menunjukkan bahwa ada hubungan antara pendidikan ayah terhadap kejadian stunting pada balita dengan risiko sebesar 2,842 kali lebih besar mengalami kejadian stunting dibandingkan dengan balita normal ( $p$-value $=0,006, \mathrm{OR}=2,842$, dan $95 \%$ CI $=1,389-5,813)$. Hasil ini tidak sejalan dengan penilitian di desa Bojonggede Kabupaten Bogor yang menunjukkan bahwa tidak ada hubungan yang signifikan antara pendidikan kepala keluarga dengan status gizi balita berdasarkan indeks TB/U. ${ }^{17}$

Menurut teori, pendidikan ayah tidak berpengaruh secara langsung dengan asupan gizi anak, tetapi dapat mempengaruhi pekerjaan ayah dan akan berpengaruh pada pendapatan keluarga. Jika ayah berpendidikan tinggi akan memiliki pekerjaan dengan pendapatan yang tinggi, sehingga pembelian makanan pun lebih tinggi dan dapat membeli makanan yang bergizi untuk anak serta anggota keluarga lainnya. ${ }^{22}$ Hal ini sejalan dengan penelitian di Kecamatan Lut Tawar, Kabupaten Aceh Tengah yang menyatakan bahwa tidak ada hubungan yang signifikan antara pendidikan ayah dengan status gizi stunting $(p$-value $=0,74)$ dengan prevalensi sebesar $22,56 \%$ pada anak stunting. ${ }^{23}$

\section{Hubungan Pekerjaan Ibu Dengan Kejadian Stunting Pada Balita}

Status ibu tidak bekerja pada kasus stunting lebih banyak sebesar 75 responden $(82,4 \%)$ dibandingkan dengan kontrol (normal) sebesar $71,4 \%$. Hasil uji chisquare menunjukkan bahwa tidak ada pengaruh antara pendidikan ibu terhadap kejadian stunting pada balita ( $p$ value $=0,113)$, sedangkan nilai CI didapatkan dengan rentang kepercayaan = 0,263-1,080 dan OR $<1$ artinya jika rentang jika rentang mendekati angka 1 menunjukkan bahwa tidak ada pengaruh yan signifikan secara statistik antara pekerjaan ibu dengan kejadian stunting.

Hasil penelitian ini sejalan dengan penelitian yang dilakukan oleh Febelina di 
kabupaten Minahasa yang menyebutkan bahwa tidak ada hubungan antara pekerjaan ibu dengan kejadian stunting pada balita dan jumlah ibu tidak bekerja lebih banyak stunting pada balita sebesar $84,7 \%$ bila dibandingkan ibu yang bekerja. ${ }^{24}$

\section{Hubungan Pendapatan Keluarga Terhadap Kejadian Stunting Pada Balita}

Besarnya pendapatan yang diperoleh oleh sebuah keluarga dapat menggambarkan status kesejahteraan dari masyarakat tersebut. Hasil penelitian ini menunjukkan bahwa pendapatan keluarga yang rendah pada kasus stunting lebih banyak sebesar 83 responden $(91,2 \%)$ dibandingkan dengan kontrol (normal) sebesar 79,1\%. Hasil uji chi-square menunjukkan bahwa ada hubungan antara pendapatan keluarga terhadap kejadian stunting pada balita dan memiliki risiko sebesar 2,738 kali mengalami terjadinya stunting dibandingkan denga balita normal. ( $p$-value $=0,037, \quad \mathrm{OR}=2,738, \quad$ dan $95 \% \mathrm{CI}=1,131-6,629)$.

Hasil penelitian ini tidak sesuai dengan penelitian yang dilakukan oleh Putri pada balita usia 6-35 bulan di Kecamatan Tembalang, Kota Semarang yang menyatakan bahwa tidak ada hubungan antara pendapatan keluarga dengan stunting pada balita ( $p$ value $=1,000) .{ }^{25}$ Hal ini dikarenakan belanja makanan sehari-hari dalam keluarga tidak sepenuhnya digunakan untuk membeli kebutuhan makanan pokok, tetapi untuk kebutuhan lainnya. Pendapatan yang tinggi tidak menjamin status gizi baik pada balita dikarenakan alokasi dana yang cukup untuk keperluan makan. ${ }^{26}$ Hasil penelitian ini sesuai dengan pernyataan Ardian pada penelitian yang dilakukan pada bayi usia 6 bulan di Kecamatan Gunung Pati yaitu tingkat pendapatan adalah faktor yang paling menentukan dalam kualitas dan kuantitas makanan dan berpengaruh terhadap kuat/lemah terhadap daya beli sehingga tidak memungkinkan untuk konsisten dalam memebri makan secara efektif pada anak ( $p$-value $=0,001, \mathrm{OR}=5,39, \mathrm{CI}=2,73$ $10,63){ }^{27}$

\section{Hubungan Pengetahuan Gizi Ibu Dengan Kejadian Stunting Pada Balita}

Pada kasus stunting, ibu yang kurang paham tentang pengetahuan gizi lebih banyak sebesar 69 responden $(75,8 \%)$ dibandingkan dengan kontrol (normal) sejumlah 25,3\%. Hasil bivariat menunjukkan bahwa pengetahuan gizi ibu yang rendah memiliki hubungan dengan kejadian stunting pada balita di Kota Semarang dan memiliki risiko 9,273 kali lebih tinggi mengalami kejadian stunting dibandingkan dengan balita normal ( $p$ value $<0,0001) \quad \mathrm{OR}=3,671, \quad \mathrm{CI}=1,640$ $8,215)$. Hasil ini sejalan dengan pendapat Suhardjo dalam bukunya yang menuliskan bahwa tingkat pengetahuan gizi seseorang akan sangat mempengaruhi sikap dan perilaku mereka dalam memilih makanan, kemudian akan berpengaruh pada keadaan individu tersebut dan lingkungan sekitar. ${ }^{28}$

Sediaoetama juga berpendapatan bahwa pengetahuan gizi dapat berpengaruh tehadap asupan gizi balita terkait dalam pemilihan makanan dan variasi makanan yang diberikan kepada anak. Perilaku gizi yang telah diterapkan oleh ibu dalam konsumsi makanan dan pengasuhan seharihari akan diikuti oleh anak dan keluarga lain. Pengetahuan gizi secara tidak langsung dapat mempengaruhi kejadian stunting melalui asupan gizi. $^{29}$ Hasil penelitian ini sesuai dengan pendapat Sediaoetama, seperti perilaku ibu dalam kurangnya memberikan variasi menu dan olahan makanan untuk anak, tidak memberi makan anak 3x makan utama dan 2x makanan selingan bernutrisi, dan tidak memperhitungkan kebutuhan gizi anak. Hal ini terkait dengan ketidak tahuan ibu dalam memberikan bahan makanan dengan gizi seimbang untuk diberikan pada anak.

Oleh karena itu, pengetahuan atau kognitif merupakan aspek yang sangat penting dan dapat berpengaruh pada 
bentuk dari perilaku seseorang termasuk pengetahuan gizi ibu, sehingga akan menjadi salah satu dari banyak faktor penyebab kejadian stunting pada anak.

\section{KESIMPULAN}

Faktor yang berhubungan secara signifikan dengan kejadian stunting pada balita dari keluarga kurang mampu di Kota Semarang antara lain pola asuh orang tua, pengetahuan gizi ibu, pendidikan ibu, pendidikan ayah, dan pendapatan keluarga.

\section{UCAPAN TERIMA KASIH}

Penulis mengucapkan terima kasih kepada Dinas Kesehatan Kota Semarang dan Puskesmas Kagok atas ijin yang diberikan untuk melaksanakan penelitian.

\section{DAFTAR PUSTAKA}

1. Bappeda Kota Semarang. Laporan Kepala Bappeda Kota Semarang Pada Acara Sosialisasi Hasil Sementara dan Pencanangan Uji Publik Kegiatan Verifikasi dan Identifikasi Warga Miskin Kota Semarang Tahun 2015. diakses dari http:simgakin.semarangkota.go.id. 2016

2. Welasasih, B. dan Wirjatmadi, R. Beberapa Faktor yang Berhubungan dengan Status Gizi Balita Stunting. Journal Public Health. 2012; Volume 8; No.3

3. Maryam, S. Gizi dalam Kesehatan Reproduksi. Jakarta: Salemba Medika; 2016.

4. Mahayu, P. Buku Lengkap Perawatan Bayi dan Balita. Yogyakarta: Saufa; 2016.

5. Kementerian Kesehatan Republik Indonesia Direktorat Jenderal Bina Gizi dan Kesehatan Ibu dan Anak. Tentang Standar Antropometri Penilaian Status Gizi Anak. Keputusan Menteri Kesehatan Republik Indonesia. 2011; K E P M E N K E S / 1995/MENKES/SK/XII/2010
6. Rusilanti, Dahlia M, Yulianti Y. Gizi dan Kesehatan Anak Prasekolah. Bandung: Remaja Rosdakarya; 2015.

7. UNICEF. Childinfo: Monitoring the Situation of Children and Women, diakses dari http://www.childinfo.org/breastfeeding. html. tanggal 11 januari 2013

8. Izwardy, D. Mewujudkan Kemandirian Keluarga Dalam 1000 Hari Pertama Kehidupan (HPK) Untuk Mencegah Stunting. Seminar Kesehatan. Kementerian Kesehatan Republik Indonesia. 2018

9. Badan Pusat Statistik Kota Semarang. Garis Kemiskinan di Kota Semarang Tahun 2012-2015. diakses dari : https://semarangkota.bps.go.id/gariskemiskinan-di-kota-semarang-2012-2015.html

10. Badan Penelitian dan Pengembangan Kesehatan. Riset Kesehatan Dasar 2013. Jakarta: Kementrian Kesehatan RI; 2013

11. Kementerian Kesehatan Republik Indonesia. Data dan Informasi Profil Kesehatan Indonesia 2017. diakses dari : h t t p : / / w w w. d e p k e s .go.id/resources/download/pusdatin/pro fil-kesehatan-indonesia/Data-danInformasi Profil-Kesehatan-Indonesia2017

12. Dinas Kesehatan Kota Semarang. Data Penentuan Status Gizi Kota Semarang. Semarang: Dinkes Kota Semarang; 2012

13. Dinas Kesehatan Kota Semarang. Hasil Pelaksanaan Bulan Penimbangan Balita (BPB) Kota Semarang Tahun 2017. Semarang: Dinkes Kota Semarang; 2017

14. Kullu, V, Yasnani, Lestari H. FaktorFaktor Yang Berhubungan Dengan Kejadian Stunting Pada Balita Usia 24-59 Bulan Di Desa Wawatu Kecamatan Moramo Utara Kabupaten Konawe Selatan. Jurnal Ilmiah Mahasiswa Kesehatan Masyarakat. April 2018; Volume 3; No.2. ISSN 2502-731X 
15. Syabandini, I, Pradigdo S, Suyatno, dan Pangestuti D. Faktor Risiko Kejadian Stunting Pada Anak Usia 624 Bulan Di Daerah Nelayan (Studi Ccase-Control di Kampung Tambak Lorok, Kecamatan Tanjung Mas, Kota Semarang). Jurnal Kesehatan Masyarakat. Januari 2018; Volume 6; No.1. ISSN : 2356-3346. diakses melalui http://ejournal3.undip.ac.id/index.php/j $\mathrm{km}$

16. Kementerian Kesehatan Republik Indonesia. Peraturan Menteri Kesehatan Republik Indonesia Tentang Sanitasi Total Berbasis Masyarakat. 2014; PERMENKES/3/MENKES/SK/II/2014

17. Hutagalung, H. Faktor-Faktor Yang Mempengaruhi Status Gizi Balita (1259 Bulan) Di Desa Bojonggede Kabupaten Bogor Tahun 2012 (Skripsi). Depok: Universitas Indonesia; 2012

18. Ni'mah C, Muniroh L. Hubungan Tingkat

Pendidikan, Tingkat Pengetahuan dan Pola Asuh Ibu dengan Wasting dan Stunting pada Balita Keluarga Miskin. Media Gizi Indonesia. 2015; vol.10; no. $1 ; 7$.

19. World Health Organization. Nutrition: complementary feeding. 2011. diakses dari

http://www.who.who.int/nutrition/topic s/complementary feeding/en/index.htm 1.

20. Renyoet B, Hadju V, Rochimiwati S. Hubungan Pola Asuh Dengan Kejadian Stunting Anak Usia 6 - 23 Bulan Di Wilayah Pesisir Kecamatan Tallo Kota Makasar Tahun 2012. diakses dari : http://repository.unhas.ac.id. 26 April 2015

21. Wijogowati, C. Kejadian Stunting Pada Anak Berumur Pada Anak Berumur Di Bawah Lima Tahun (0-59 Bulan) Di Provinsi Papua Barat Tahun
2010 (Skripsi). Depok: Universitas Indonesia; 2010

22. Akombi, B. J., Agho, K. E., Hall, J. J., Merom, D., Astell-Burt, T., dan Renzaho, A. M. Stunting and Severe Stunting Among Childrewn Under-5 Years in Nigeria:A Multilevel Analysis. BMC Pediatrics. 2017; vol 17; no.1; 116.

23. Basri A, Sudargo T, dan Susilo J. Hubungan sosial ekonomi, pola asuh, pola makan dengan stunting pada siswa sekolah dasar di Kecamatan Lut Tawar, Kabupaten Aceh Tengah. Jurnal Gizi dan Dietetik Indonesia; September 2013; vol 1; no.3; 121-130.

24. Nauw, F, Punuh M, Malonda N. Hubungan Antara Sosial Ekonomi Dengan Kejadian Stunting Pada Balita Di Pulau Mantehage Kecamatan Wori, Kabupaten Minahasa Utara. Jurnal Publikasi. Manado: Universitas Sam Ratulangi; 2016

25. Anindita, P. Hubungan Tingkat Pendidikan Ibu, Pendapatan Keluarga, Kecukupan Protein\&Zinc Dengan Stunting (Pendek) Pada Balita Usia 635 Bulan Di Kecamatan Tembalang Kota Semarang. Jurnal Kesehatan Masyarakat; 2012; vol 1; no.2; 617626.

26. Dayat. Pendapatan per Kapita dan Kesempatan Kerja. diakses dari : http://edukasi.net/index.php

27. Candra, A, Subagio, H dan Margawati, A. Determinan Kejadian Stunting Pada Bayi Usia 6 Bulan Di Kota Semarang. Jurnal Gizi Indonesia; Juni 2016; vol 4; no. $2 ; 82-88$. ISSN:1858-4942

28. Suhardjo. Sosio Budaya Gizi. Bogor: IPB PAU Pangan dan Gizi; 1989.

29. Sediaoetama, A. Ilmu Gizi Untuk Mahasiswa dan Profesi. Jakarta: Dian Rakyat; 2008 